綜 説 (Review Article) : 膜 (MEMBRANE), 19 (2), 75-80 (1994)

\title{
経皮治療システムに使われる高分子材料
}

\author{
東 條 角 治
}

九州工業大学 情報工学部治療システム研究室 雪 820 福岡県飯塚市川津 680-4

\section{Polymers for transdermal drug delivery systems}

\section{Kakuji Tojo}

Division of Therapeutic Systems Research, College of Computer Science and Systems Engineering, Kyushu Institute of Technology, Iizuka Campus, Fukuoka 820, Japan

A variety of biocompatible polymers can be used for developing transdermal delivery systems of systemic drugs. This paper reviews some methods for the selection of drug/polymer matrix, adhesives and rate-controlling membranes.

Key words : transdermal delivery, drug delivery, polymers, rate-control membranes, adhesives

\section{1.はじめに}

経皮治療システムのデバイスは，一般に薬物保存層の 両側をポリマー膜で挟んだ多層膜構造である. 外部の バッキング膜は不透過性のポリマーやアルミフォイル で, 表面からの薬物の損失を防ぐ構造になっている. 一 方皮膚側表面は粘着層あるいは放出速度制御膜である. 薬物の放出メカニズムの相違により, 経皮治療システム は, 次の 2 つに分類される ${ }^{1)}$.

1). 均一層マトリックス製剤: 薬物はポリマーマト リックス中に溶解もしくは分散している. 放出速度は時 間とともに減少する（図 1-a).

2).レザバー型膜製剤：ポリマー膜の拡散抵抗が薬物 放出速度を支配する (図 1-b).

経皮治療システムとしてマトリックス型製剤を用いる かそれともレザバー型製剤を採用するかは, 皮膚吸収速 度と血中への移行速度を支配する因子を考慮して決めら れる. 皮膚吸収の総括的な抵抗は, デバイス中の拡散抵 抗 $\left(R_{1}\right)$, 角質層の拡散抵抗 $\left(R_{2}\right)$ および生きた表皮層 の拡散抵抗 $\left(\mathrm{R}_{3}\right)$ の和で表される. しかし大抵の場合, 生きた表皮層での拡散抵抗は他の抵抗に比べ無視できる 程度である. 電気回路における電流と相似な関係から,
総括的な透過速度は 3 つの抵抗の和 $\left(R_{1}+R_{2}+R_{3}\right)$ に反 比例する. もし $R_{2}>>R_{1}>R_{3}$ なら, 薬物の皮䖉透過 速度は角質層の透過抵抗に支配される. また $\mathrm{R}_{1}>>\mathrm{R}_{2}>>\mathrm{R}_{3}$ なら, デバイス内の薬物拡散抵抗が皮膚 透過速度を支配する.

治療に必要な薬物量が角質層の透過可能量より十分少 ない場合は, デバイスデザインによって有効血中濃度を 制御できる.このようなデバイスは膜制御型システムで, 放出速度制御用ポリマー膜が用いられる. 一方角質層の 透過が律速段階ならマトリックス型システムで十分であ る. 副作用発現最低血中濃度と無効域最高血中濃度との 比は治療指標 (Therapeutic Index) として定義される が,この治療指標と皮膚透過に現れる個体差もデバイス デザインを決定する上で重要な基準である. 治療指標が 1 に近く有効治療濃度域の狭い薬物にはマトリックス型 システムは好ましくない．ここでは, 2 種類の経皮治療シ ステムとそこに用いられるポリマーについて概説する.

\section{2.レザバー型デバイス}

狭心症の治療薬ニトログリセリンの経皮治療システ ム, ニトロダーム (Ciba Geigy) は, 典型的なレザバー 


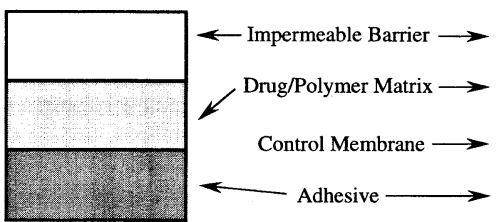

(a)

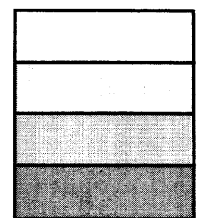

(b)
図 1. 経皮治療システム概略

(a) マトリックス型システム, (b) 膜制御型システム.

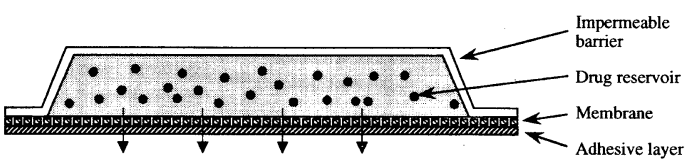

図 2. 膜制御型ニトログリセリン経皮治療システ ム（トランスダームニトロ）

型 (膜制御型) デバイスである（図 2).このシステム には, 粉末乳糖に結合した薬効成分ニトログリセリンが シリコーンオイル中に分散して薬物保存層を形成し，工 チレン酢酸ビニル共重合ポリマー薄膜で放出制御され る.このようなレザバー型システムでは, 薬物保存層の 濃度が一定（飽和濃度）に保たれる限り皮膚透過速度は 次式で示す一定速度になる。

$$
\mathrm{J}=\mathrm{ADK} \Delta \mathrm{C} / \mathrm{l}
$$

ここで, $\mathrm{A}=$ 有効膜表面積, $\mathrm{D}=$ 膜内拡散係数, $\mathrm{K}=レ$ ザバー/膜間分配係数, $\Delta \mathrm{C}=$ 膜に接する両媒体間濃度 差, $1=$ 膜厚み, である.

図 3 に示すようにこのシステムからの薬物の放出速度 は24時間にわたり一定に保たれる ${ }^{2)}$. ただし初期のわ ずかのバースト効果（破裂的放出）は粘着層に含まれて いる薬物の放出によるもので, 皮膚透過の長い時間遅れ が問題になる薬物に対して効果的である.

\section{3. マトリックス型デバイス}

マトリックス型デバイスはポリマーマトリックス中に 含まれている薬物の分散状態により 2 種類に分類され る. 1 つは薬物が溶解している（飽和濃度以下で溶解し ている）システムで, 他は飽和濃度以上で分散している 場合である. マトリックス溶解型システムからの累積薬 物放出率は次式で与えられる.

$$
\mathrm{F}=2\left(\mathrm{Dt} / \pi 1^{2}\right)^{1 / 2} \text { for } \mathrm{F}<0.6
$$

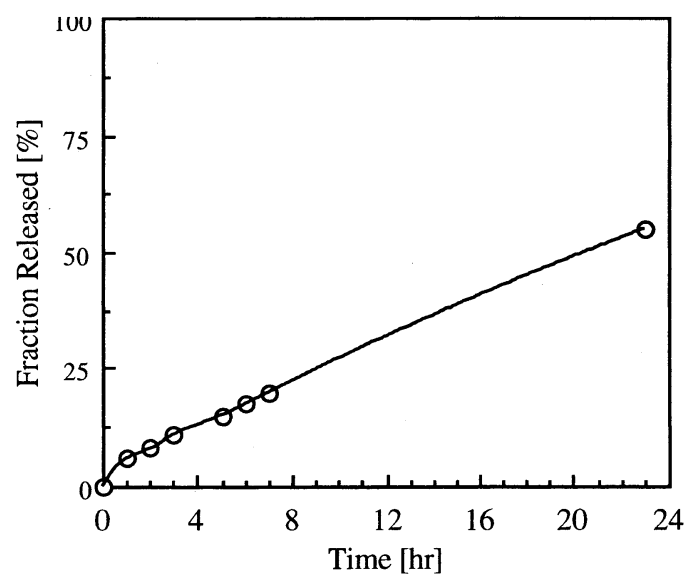

図3.トランスダームニトロシステムからのニト ログリセリン放出特性

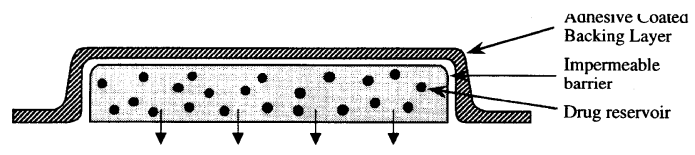

図 4. マトリックス溶解型 NTS システム

Bolar 社の NTS システム (Nitroglycerin Transdermal System) はマトリックス溶解型ニトログリセ リン経皮治療システムである.ここではニトログリセリ ンが塩化ビニル / 酢酸ビニル共重合体に溶解している. さらに不透過ポリエステルのバッキング粘着層で薬物 / ポリマーマトリックスを包み込む構造である（図 4). このシステムからの薬物放出は図 5 に示すように時間の 平方根に比例し ${ }^{2)}$ ，(2)式に従うことがわかる.

薬物分散型のマトリックスシステムでは, 薬物の保存 量が飽和濃度より十分大きい場合, 薬物放出速度は次式 で与えられる。

$$
\mathrm{J}=\mathrm{A}\left(\mathrm{DC}_{s} \mathrm{C}_{o} / 2 \mathrm{t}\right)^{1 / 2} \text { for } \mathrm{C}_{o} \gg \mathrm{C}_{s}
$$

ここで $\mathrm{C}_{o}=$ 初期薬物保存量, $\mathrm{C}_{S}=$ 薬物飽和濃度, $\mathrm{A}=$ 有効膜表面積である.

\section{4. 経皮治療システムのポリマー膜}

薬物保存層のポリマーは種々の因子を考慮して注意深 く選択される. 皮膚科製剂や化粧品のクリームや軟膏の 製剂化と同様に，経皮治療システムのマトリックス製剂 設計は科学的な面と経験的な面との両面を備えている. 

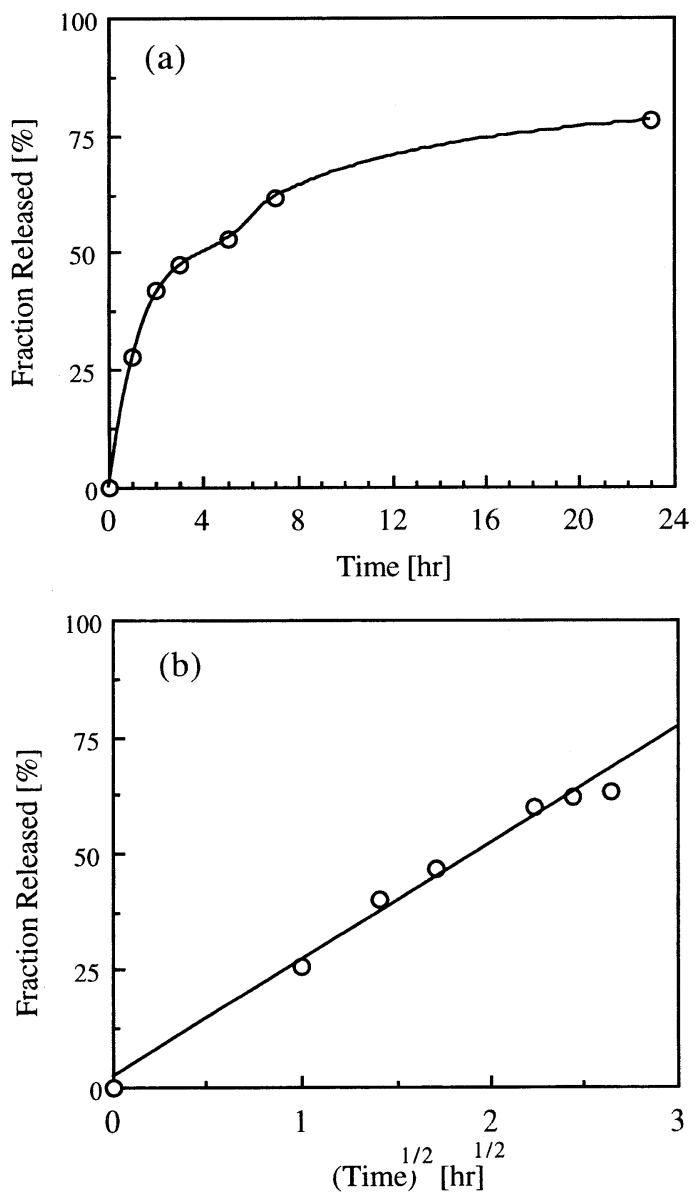

図 5. マトリックス溶解型 NTS システムからのニ トログリセリン放出特性

製剤設計で考慮すべき基準は次のような点である.

ポリマー内の薬物拡散係数と溶解度

薬物保存量とポリマー構造に及ぼす影響

溶剤, 透過促進剤など添加物とポリマーとの適合性 デバイス構造 : マトリックス型あいは膜制御型

皮膚との適合性

機械的強度と感度

製造方法

毒性と純度

コストと供給度

など

上記の基準を満たし経皮治療システムに用い得るポリ マーは, ポリイソブチレン, ポリアクリレート, ポリシ ロキサン, 塩化ビニル /酢酸ビニル共重合体, ヒドロゲ ルなどである.

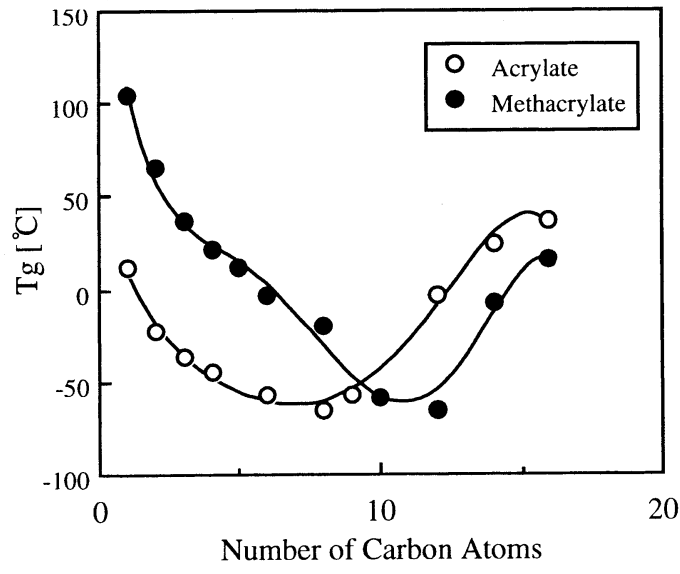

図6.アクリル系およびメタアクリル系エステル ポリマーのガラス転移温度

\section{1 ポリイソブチレン ${ }^{3)}$}

ポリイソブチレン (PIB) は非極性無定形パラフィン 系炭化水素ポリマーで直鎖の高分子からなっている：

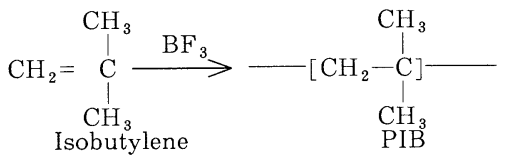

PIB の物性は分子量とともに変化する. 分子量が大 きくなるとポリマー液粘性が増大しついにバルサム状粘 着個体になり, 粘弾性ポリマーを形成する. 薬物／ポリ マーマトリックスは, 異なる PIB 分子量とミネラルオ イルなどの添加物との混合によって最適設計される. PIB は炭化水素溶媒に可溶だが極性溶媒には溶けない. また無定形, 飽和性, 低ガラス転移温度などのため柔軟 性と抗酸化性にすぐれている.

\section{2 ポリアクリレート}

アクリル酸エステルとメタアクリル酸エステルとのコ ポリマーは薬物を含むポリマーマトリックスとしてすぐ れている. このコポリマーはアクリルモノマーのフリー ラジカル共重合で合成される：

$\underset{\mathrm{CH}_{2}=\mathrm{CH}}{\mathrm{CO}_{2} \mathrm{R}_{1}}+\mathrm{CH}_{2}=\mathrm{CH} \underset{\mathrm{R}^{0}}{\stackrel{\mathrm{CO}_{2} \mathrm{R}_{2}}{\longrightarrow}}\left[\begin{array}{c}\mathrm{CH}_{2}-\mathrm{CH}-\mathrm{CH}_{2}-\mathrm{CH} \\ \text { Acrylate copolymer }\end{array}\right]$

アクリル系ポリマーはやや極性をもち無色透明で化学 的抵抗にすぐれ, 熱, 光, 酸化剂に対しても安定である. デバイス使用温度より十分低いガラス転移温度 Tg のポ 
リマーが薬物／ポリマーマトリックスとして使用され る. アクリルおよびメタアクリル酸エステルポリマーの 炭素数とガラス転移温度 $\mathrm{Tg}$ との関係を図 6 に示す ${ }^{1)}$. この図から明らかなように, ポリマーの Tg は鎖の剛さ の関数である. メタアクリレートの場合, 主鎖のメチル グループが剛さに寄与している. メチルメタアクリレー トとメチルアクリレートとの $\mathrm{Tg}$ には約 $100^{\circ} \mathrm{C}$ の差があ る. しかし側鎖が長くなるにつれ柔軟性が増大するので $\mathrm{Tg}$ は低下する. アルキルグループ炭素数がアクリルで 8 , メタアクリルで 12 を越すと, 側鎖の結晶化が起こり, ポリマーの柔軟性を妨げるので Tg は上昇する。適当な アクリルあるいはメタアクリルモノマーの共重合によ り，最適な物性をもつコポリマーが得られる.

\section{3 ポリシロキサン}

ポリシロキサン(シリコーン)は有機シリコンポリマー で Si-O-Si 結合のシリコン原子に種々のアルキルグ ループが付加している. Si の両サイドにメチル基をも つポリマーがもっとも一般的なポリジメチルシロキサン PDMS である. 抗熱, 抗酸化にすぐれ化学物質に対し ても安定で非常に表面張力が小さいなど特有の性質であ

る. PDMS のガラス転移温度は低く, 薬物透過性が高 い. 経皮治療システムに用いるポリシロキサンの性状は 液 (オイル状), エラストマーおよび樹脂で, クロロシ ランの加水分解によって合成される.

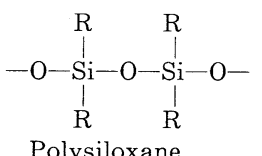

$$
\text { Polysiloxane }
$$

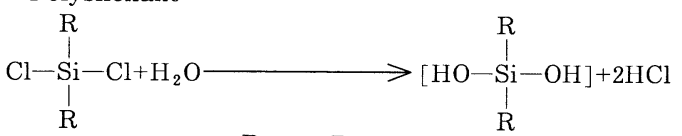<smiles>[R][SiH]([R])[Si]([R])([R])O[Si]([R])([R])OC</smiles>

薬物／ポリマーマトリックスは, 低分子量のシリコー ンオイルあるいはペーストに薬剤を分散した後, 架橋し てエラストマーに形成される.

\section{4 親水性ポリマーゲル}

治療効果の期待できるポリマー内薬物拡散係数や熱力 学的活性を得るために親水性ポリマーゲルがいくつかの 薬物に対して用いられている. ヒドロゲルは, イオント
フォレシスのような通電性が必要な場合にとくに適して いる.

ポリビニルピロリドンノポリビニルアルコール : PVP, PVA, グリセリンのような可塑剤および水をやや高温 度 (約 $90^{\circ} \mathrm{C}$ ) で均一混合し, 温かいうちにフィルム状 ゲルマトリックスに成型される.

ヒドロゲル：ヒドロゲルは水を含んで膨潤するが水に は溶けない親水性ポリマーである，共有結合，イオン結 合, 水素結合などで架橋される. 合成ヒドロゲルの含水 率は $30 \%$ から $90 \%$ 以上まで多岥にわたる. 2-ヒドロキ シメタアクリレート, n-ビニル-2-ピロリドン, アクリ ルアミドなどの親水性モノマーのフリーラジカル共重合 によって合成される，ゲルの含水率は架橋度で制御でき るし，親水性／疏水性モノマーの比率でも調整できる.

\section{5 塩化ビニルポリマーとコポリマー (PVC)}

薬物／ポリマーマトリックスに用いられる塩化ビニル ポリマーや PVC は塩化ビニルのホモポリマーや塩化ビ ニル高含有率のコポリマーである. PVC は非常に硬い 材質なのでそれだけで経皮治療システムに用いられるこ とはほとんどない. ジオクチルフタレート，エポキシ化 大豆油, クエン酸エステルなどの可塑剤とともに用いら れる.これら可塑剤の含有比率は $20 \%$ から $75 \%$ にわた る. 薬物を分散した PVC フィルムは溶剤法でも成型で きるが，溶剤を用いない PVC プラスチゾル法が望まし い.この方法は, 可塑剤中に PVC 樹脂を分散したペー スト（プラスチゾル）に薬物を分散した後，混合物を適 当な厚みに成型する.この場合, $130 \sim 160^{\circ} \mathrm{C}, 1$ ないし 3 分で PVC は可塑剂に溶解し, 薬物を含んだ柔らかい フィルムになる．薬物の皮膚吸収は可塑剤の性質，その 含有量, 薬物保存量の 3 因子に依存する.

\section{5. 粘着剂 ${ }^{4}$}

粘着は濡れをともなう接着として定義できる．経皮治 療システムに使われる感圧接着 (PSA) では, 皮膚に押 しつけるとはじめに接着剂の液状流動をともなう．圧力 を取り除くとその状態で皮膚に接着する. 剝がれないだ けの十分な粘着力を得るために粘弾性エネルギーが, 結 合／脱着プロセスに貯蓄されている. したがって感圧粘 着は, ガラス転移温度より十分高い温度で, 粘弾性物質 に特徵的性質である.

経皮治療システムにおける PSA は種々の粘弾性の程 


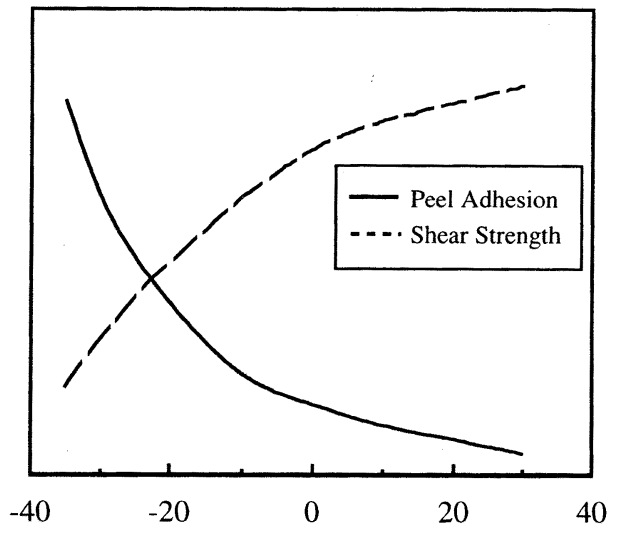

Glass Transition Temperature, $\operatorname{Tg}\left[{ }^{\circ} \mathrm{C}\right]$

図 7. 引き剝がし粘着力とせん断力におよぼすア クリルコポリマーのガラス転移温度の影響

度に依存する. よく用いられる PSA は, アクリル系コ ポリマー, ポリイソブチレン, ポリシロキサンなどであ る. 粘着剤の選択は皮膚刺激性, 感作, 粘着力, 脱着の 容易さなどを考慮して決められる. 粘着層に薬物を分散 した粘着層マトリックスでは薬物と添加物は粘着層を拡 散するので, 粘着力が薬物や透過促進剂に影響されない よう設計される. また, 粘着剤は総括的な薬物送達速度 を変化してはならない。

\section{1 アクリル系 PSA}

よく用いられるアクリル系 PSA は，アクリロニトリ ル, アクリル酸, アクリルアミドなどの $\mathrm{C}_{4}$ から $\mathrm{C}_{8}$ の アルキル基をもつコポリマーである. メチルおよびエチ ルアクリレート, メチルメタアクリレート, スチレンあ るいは酢酸ビニルなどのモノマーが物性調節のために用 いられる.

粘着剤の性質はポリマーの共重合化に依存する. $\mathrm{C}_{4}$ から $\mathrm{C}_{8}$ のアルキルアクリレートは共重合体に柔軟性を 与える．極性モノマーを少量加えると皮膚粘着力が増大 する. 物性調節モノマーはガラス転移温度を变化し粘着 強度を増大する. PSAの Tg はシステム使用温度より 十分低くなければならない. 使用温度と $\mathrm{Tg}$ との差が大 きいと適用圧力での粘性流れのため濡れを増加し粘着力 を低減する. したがって濡れと接着力のバランスに最適 な $\mathrm{Tg}$ が必要である. 引き剝がし力とせん弾力におよぼ すアクリレートとコポリマーの Tg の影響を図 7 に示 す4).

アクリル系 PSA の利点のひとつは単一成分の点であ

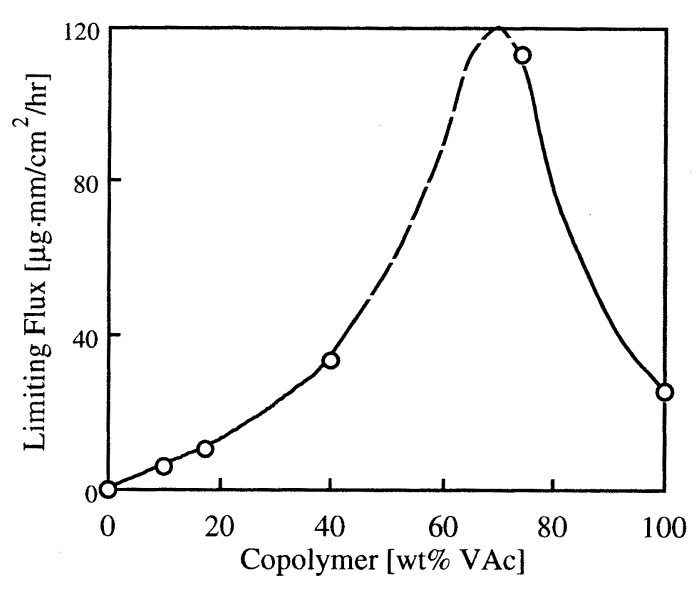

図 8. EVA コポリマー膜からのカンフル透過速度

る. 粘着付与剤, 增量剂, 安定剂などの低分子添加物を 含まないので, 皮膚との適合性もよく粘着力も安定して いる. アクリル系粘着剤はすぐれた熱, 酸化, 紫外光安 定性がある.ささらに水蒸気透過性にすぐれるので経皮治 療システムにおける皮膚のふやけを防ぐことができる.

\section{2 ポリイソブチレン}

ポリイソブチレン (PIB) 感圧粘着剤は, 低分子之高 分子の PIB を混合して形成される. ポリテルペン型樹 脂やパラフィン油のような液状可塑剤を加えることもあ る. 高分子 PIB は粘弾性と凝集力にすぐれ, 低分子 PIB は粘着力を増大する.

低い $\mathrm{Tg}$ のため PIB 粘着剤は柔軟性にすぐれている. しかし非極性なのでアクリル系粘着剤のような強い粘着 力を示さない. さらに水蒸気透過性も低い.

\section{3 ポリシロキサン}

ポリシロキサン PSA は PDMS ガムとシリケート樹 脂の縮合重合で合成される. 治療には有効な PSA 物性 はガム之樹脂の最適配合で得られる. 樹脂の含有量は 50 ないし $70 \%$ である. 組成の粘着力は樹脂含有量の増加 とともに低下する. ポリシロキサン PSA は皮膚適合性, 低毒性, 高水蒸気透過性などすぐれた特徵をもっている.

\section{6. 速度制御膜 ${ }^{5)}$}

膜制御型経皮治療システムに用いられるポリマー膜は 非常に多岐にわたる，オレフィン系ポリマー，コポリ マー, セルロースエステル, ポリアミド, ポリ塩化ビニ 
ルなどである. ポリマー膜は薬物膜内挙動の相違によっ て, 分子拡散型膜之微小多孔質膜とに分類される. 分子 拡散型ポリマー膜の拡散速度は, 高分子鎖の分子配向, 充壃度, 結晶度などに反映されるモーフォロジーの関数 となる。

酢酸ビニルエチレン共重合体 (EVA) は分子拡散型ポ リマー膜としてすぐれている. 薬物の拡散速度は酢酸ビ ニルの比率によって広範囲に制御できる. 低密度ポリエ チレンは結晶度 50 ないし $60 \%$ で約 $115^{\circ} \mathrm{C}$ の融解度で ある.しかしエチレンが酢酸ビニルと共重合化するとき, 結晶度と結晶融解度が低下する. EVA 共重合体の薬物 の拡散は無晶質部でおこるので, 結晶度が低下するにつ れ, 薬物透過度が増大する. さらにエチレンと酢酸ビニ ルの共重合化はポリマーの極性を増加する.したがって, 酢酸ビニルの増加は薬物溶解度を増大し, ポリマー内の 極性分子の拡散を促進する. しかし, 酢酸ビニル量が $60 \%$ を越えると, コポリマーの $\mathrm{Tg}$ を $-25^{\circ} \mathrm{C}$ から約 $35^{\circ} \mathrm{C}$ に上昇する. $\mathrm{Tg}$ の上昇は高分子鎖のモビリティを減少 するので, 薬物の拡散係数は減少する. 共重合体組成の 薬物の膜透過性におよぼす影響を, モデル薬物カンフル について図 8 に示す5).

細孔性ポリマー膜としてはセルロースエステル，ポリ オレフィン, イソタクチックポリプロピレンなどが使わ れる. 細孔性ポリマー膜の半透過性は, 薬物の断面積の 大きさに起因する. すなわち小分子は大分子より透過性 にすぐれている. また, 直線的分子は側鎖のある分子や 球状分子よりよく透過する. 薬物拡散には分子の平均自 由行路の少なくとも数倍の孔径が必要でふつう $100 \AA$ か ら数 $\mu \mathrm{m}$ 程度である. 細孔性ポリマー膜は光を散乱する ので透明な材質で作られていても不透明である.

\section{7. おわりに}

経皮治療システムに用いられる代表的なポリマーを概 説した. マトリックス型システムと膜制御型システムで は，デバイスからの薬物放出特性は異なり，とくに膜制
御型システムは皮膚透過速度を膜の厚みやモーフォロ ジーで一定に制御できる点で治療効果の個体差を最小に できる大きな利点をもっている．しかし経皮治療システ ムの開発研究でもっとも重要なステップは治療効果の期 待できる最低有効血中濃度を維持できる透過促進剤やそ の濃度を実現することで, この課題に最も大きな労力が 費やされる，そのため大抵の経皮治療システムは皮膚角 質層制御型である. すなわち薬物の皮膚透過速度が皮膚 の透過抵抗に支配されるので, マトリックス構造も膜制 御型製剤も血中への薬物移行挙動に大きな差を生じない のがふつうである. しかし最近, 皮膚内部構造の動的変 化や透過促進機構を分子レベルで解明しようとする意欲 的な研究が各国で進展しており, 近い将来, 強力で安全 な透過促進法が開発されると期待できる. また, 一定透 過速度ばかりでなく, 時間に依存する透過速度の動的制 御の有効性も, 耐性の防止や生体のリズムを考慮した治 療システムとして期待されるようになっている.このよ うな新しい目的を満たす経皮治療システムは, 総括的な 皮膚透過速度を皮膚によらずデバイスに依存するようデ ザインされるべきである. 経皮治療システムのポリマー の選択が今後ますます重要な課題になると考えられる.

\section{文献}

1) T. J. Franz, K. Tojo, K. R. Shah, A. Kydonieus, "Transdermal delivery" in "Treatise on controlled drug delivery", Edited by A. Kydonieus, Chapt. 8, Marcel Dekker, New York, pp. 341-421, 1993.

2) V. P. Shah, N. W. Tymes, J. P. Skelley, J. Control. Rel., 7, 79 (1988).

3) D. J. Enscore, R. M. Gale, U. S. Patent 4, 559, 222 (1985).

4) D. Satas (Ed.) "Handbook of pressure sensitive adhesive technology", 2nd ed., Van Nostrand Reinold, New York, 1989.

5) R. W. Baker, "Controlled release of biologically active agents”, John Wiley, New York, pp. 161-162, 1989.

（受付 1994 年 1 月 17 日） 